\title{
Editorial
}

\section{Treating coronaries, at home or away?}

Direct angioplasty for acute myocardial infarction is either an unnecessary luxury or the greatest thing since sliced bread, depending on your persuasion. ${ }^{1}$ It has been argued by proponents of thrombolysis that it is impractical to consider angioplasty in most instances because the majority of patients with acute infarction present to hospitals without the facilities to perform it. In this edition of Heart, Zijlstra et al challenge this premise. ${ }^{2}$ They compared the outcome of 104 patients with acute infarction referred for direct angioplasty from peripheral hospitals, with 416 patients who presented to the tertiary institution. Despite the fact that the patients transferred were generally of higher risk, they did just as well as those who presented directly. Importantly, the overall ischaemic time was similar in both groups. Careful organisation meant that the time lost in transportation was made up by avoiding delays in vacating catheter laboratories.

There are obvious limitations to the study that the authors acknowledge. Essentially it was a non-randomised, retrospective audit, conducted in a demographically compact part of the Netherlands. For more than $90 \%$ of patients, the distance between the hospitals was less than $50 \mathrm{~km}$. Restoration of coronary flow was achieved in $78 \%$ of the transferred group within six hours of the onset of pain. Thus the data may not apply to more rural parts of the world or to cities with worse traffic congestion.

\section{Thrombolysis and angioplasty: comrades or competitors?}

A considerable number of column inches has been devoted to the question of the optimal reperfusion strategy for acute infarction. ${ }^{3}$ As is the custom of the day, advocates use the same information gleaned from the few, small, randomised studies and non-randomised registries, and come up with diametrically opposing conclusions. ${ }^{1}$ It is likely that the two techniques have similar efficacy, angioplasty perhaps being better but with added initial cost and inconvenience for the cardiologist. ${ }^{4}$ It is possible that the magnitude of the benefit is not as great as suggested by the original randomised studies. ${ }^{5}$ What is unfortunate is that the two main reperfusion strategies are portrayed as competitive. Their complementary potential is frequently ignored.

\section{Which patients may benefit from access to direct angioplasty services?}

Thrombolysis has been the mainstay of treatment for acute myocardial infarction for over 10 years. Thousands of patients have been randomised in trials and its benefits are beyond question. ${ }^{6}$ It is unlikely that there will be a major shift in favour of angioplasty in the near future. However, thrombolysis has limitations that might be addressed by angioplasty. The most serious limitation is the list of contraindications. Such is the monopoly of thrombolysis in many physicians' estimation that no other treatment is entertained. Up to $20 \%$ of patients presenting with acute myocardial infarction receive no reperfusion therapy at all and have a worse outcome. ${ }^{7}$ The data of Zijlstra et al should serve as a reminder that such patients could do well with angioplasty. ${ }^{2}$

There are other groups of patients presenting with myocardial infarction for which there is evidence that thrombolysis may not be the treatment of choice. The GISSI-1 study was the only one of the large placebo controlled thrombolytic trials to include patients with unequivocal cardiogenic shock. There was no evidence of improved survival in this group. ${ }^{8}$ On the other hand, large case series have suggested an improved survival with angioplasty. ${ }^{9}$ In addition, the GUSTO-1 study patients with previous coronary artery bypass grafting did less well than those without a surgical history. ${ }^{10}$ Conventional intravenous doses of thrombolytic agents may be insufficient to deal with the thrombus burden in a saphenous vein graft. The same may apply to subacute stent thrombosis.

Angioplasty may have a role after thrombolytic failure. Thrombolysis is ineffective in achieving satisfactory (TIMI-3) reperfusion in $50 \%$ of circumstances. ${ }^{11}$ The short and long term outcomes of those with persistent occlusion is much worse than if the artery is patent. ${ }^{12}$ Although Zijlstra et al did not include patients in this group, "rescue" angioplasty after thrombolytic failure has been demonstrated to be of benefit, at least in those with anterior infarction..$^{13} \mathrm{~A}$ logical role for angioplasty would be in a patient with persisting pain and ECG changes after thrombolytic therapy. In Zijlstra et al's study ${ }^{2}$ the mean time between presenting to the referring hospital and balloon inflation was around 90 minutes for patients who received treatment within six hours of pain onset. These short transfer times suggest that it may be profitable to explore the question of routine rescue angioplasty if thrombolysis has failed.

\section{Access to direct angioplasty services}

Transportation of patients with acute infarction is probably only feasible in geographically compact areas where transportation times are short. Modern ambulances can carry much of the necessary equipment and modern intra-aortic balloon pumps are easily portable and have a battery life of hours. With appropriate escorts, transferral of even very sick patients is possible. In the study by Zijlstra et al only one death occurred during transportation in a patient in cardiogenic shock. ${ }^{2}$

In geographically remote regions, it is unlikely that transportation is feasible. In such circumstances, there is a case for small volume, stand alone angioplasty units staffed by appropriately experienced personnel. A number of such units have published their experience and the results compare well with those from large volume centres. ${ }^{14-16}$ Crucial to the question of isolated units is the place of surgical back up. Although it is possible that angioplasty could destabilise the situation, it is unlikely. This is particularly so with the advent of flexible stents and better antiplatelet therapy. Therefore, surgery for angioplasty complications is not a prerequisite, particularly if this risk is offset against the risk of no reperfusion therapy.

\section{Conclusion}

Zijlstra et al end their discussion by calling for a randomised trial. ${ }^{2}$ Many aspects concerning direct angioplasty require such studies. However, without the major sponsorship accorded to the thrombolytic megatrials, it is unlikely that a study of sufficient size and power will be conducted to convince thrombolysis devotees. However, 
even the most monotherapeutic physician should remember that direct angioplasty has a place in infarct management. They should remain on good terms with their nearest angioplasty service (or develop one locally).

DAVID W SMYTH

JOHN M ELLIOTT

Department of Cardiology,

Christchurch Hospital,

Christchurch, New Zealand

1 Lange RA, Hillis LD, Grines CL. Should thrombolysis or primary angioplasty be the treatment of choice for acute infarction? $N$ Engl f Med 1996;335:1311-16.

2 Zijlstra F, van't Hoff AWJ, Liem AL, Hoorntje JCA, Suryapranata H, de Boer MJ. Transferring patients for primary angioplasty: a retrospective analysis of 104 selected high risk patients with acute myocardial infarction. Heart 1997;78:333-6.

3 International Round-up. Primary angioplasty in acute myocardial infarction. Br Heart f 1995;73:403-16.

4 GUSTO IIb Angioplasty Substudy Investigators. A clinical trial comparing primary coronary angioplasty with tissue plasminogen activator for acute myocardial infarction. N Engl f Med 1997;336:1621-8.

5 Michalis KB, Yusuf S. Does PTCA in acute myocardial infarction affect mortality and infarction rates? A quantitative overview (meta-analysis) of the randomized clinical trials. Circulation 1995;91:476-85.

6 Fibrinolytic Therapy Trialists' Collaberative Group. Indications for fibrinolytic therapy in suspected acute myocardial infarction: collaborative
overview of early mortality and major morbidity reults from all randomized overview of early mortality and major morbidity reults from all randomized
trials of more than 1000 patients [correction, Lancet 1994;343:742]. Lancet trials of more than
7 French JK, Williams BF, Hart HH, Wyatt S, Poole JE, Ingram C, et al. Prospective evaluation of eligibility for thrombolytic therapy in acute myocardial infarction. BMF 1996;312:1637-41.

8 Gruppo Italiano per lo Studio della Streptochinasi nell'Infacto Myocardico (GISSI). Effectiveness of intravenous thrombolytic therapy in acute myocardial infarction. Lancet 1986;i:397-401.

9 Lee L, Erbel R, Brown TM, Laufer N, Meyer J, O’Neill W. Multicentre registry of angioplasty therapy of cardiogenic shock: initial and long term sur-
vival. $\mathcal{F}$ Am Coll Cardiol 1991;17:599-603.

10 DeFranco AC, Abramowitz B, Krichbaum D, Topol EJ. Substantial (threefold) benefit of accelerated t-PA over standard thrombolytic therapy in patients with prior bypass surgery and acute MI: results from the GUSTO trial [abstract]. F Am Coll Cardiol 1995;23:345A.

11 The GUSTO Angiographic Investigators. The effect of tissue plasminogen activator, steptokinase or both on coronary artery patency, ventricular
function, and survival after acute myocardial infarction. $N$ Engl $7 \mathrm{Med}$ function, and surviva

12 White HD, Cross DB, Elliott JM, Norris RM, Yee TW. Long-term prognostic importance of patency of the infarct-related coronary artery after thrombolytic therapy for acute myocardial infarction. Circulation 1994;89: 61-7.

13 Ellis S, da Silva ER, Heyndrickx G, Talley JD, Cernigliaro C, Steg G, et al, For the RESCUE Investigators. Randomized comparison of rescue angioplasty with conservative management of patients with early failure of thrombolysis for acute anterior myocardial infarction. Circulation 1994;90: 2280-4.

14 Weaver WD, Litwin PE, Martin JS, for the Myocardial Infarction Triage and Intervention Project Investigators. Use of direct angioplasty for treatment of patients with acute myocardial infarction in hospitals with and without on-site cardiac surgery. Circulation 1993;88:2067-75.

15 Brodie BR. Primary angioplasty in a community hospital in the USA. $\mathrm{Br}$ Heart f 1995;73:409-10.

16 Smyth, DW, Richards AM, Elliott JM. Direct angioplasty in myocardial infarction in a hospital with surgical back-up 220 miles away. $f$ Intervent Cardiol 1997;9:324-32. 